Joyful Learning Journal

\title{
HUBUNGAN POLA ASUH ORANG TUA DENGAN KEMAMPUAN BERFIKIR KRITIS SISWA
}

Efrilia Nur Rahmawati ${ }^{\bowtie}$, Eko Purwanti

Jurusan Pendidikan Guru Sekolah Dasar, Fakultas Ilmu Pendidikan, Universitas Negeri Semarang, Indonesia

\begin{tabular}{l} 
Info Artikel \\
\hline Sejarah Artikel: \\
Diterima Jan 2021 \\
Disetujui Feb 2021 \\
Dipublikasikan Mar \\
2021
\end{tabular}

Keywords:

students critical thinking skills; parenting styles

\begin{abstract}
Abstrak
Tujuan penelitian ini untuk mengetahui hubungan yang positif dan signifikan antara pola asuh orang tua terhadap kemampuan berfikir kritis siswa SDN Kecamatan Teras Kabupaten Boyolali. Penelitian ini merupakan penelitian korelasi dengan pendekatan kuantitatif. Subjek penelitian adalah siswa kelas III SDN Kecamatan Teras Kabupaten Boyolali. Populasi dalam penelitian ini berjumlah 190 siswa dan sampel berjumlah 128 siswa dengan teknik pengambilan sampel menggunakan teknik purposive sampling. Teknik pengumpulan data menggunakan angket, dokumentasi, wawancara dan observasi. Teknik analisis data yang digunakan yaitu statistika deskriptif, uji hipotesis, dan koefisien determinasi. Hasil penelitian menunjukan bahwa terdapat hubungan positif dan signifikan antara Pola asuh orang tua terhadap kemampuan berfikir kritis siswa dengan koefisien korelasi sebesar 0,775 dan nilai signifikansi 0,00 . Dari hasil penelitian dapat disimpulkan bahwa terdapat hubungan yang positif dan signifikan antara pola asuh orang tua dengan kemampuan berfikir kritis siswa kelas III SDN Kecamatan Teras Kabupaten Boyolali.
\end{abstract}

C 2021 Universitas Negeri Semarang

\footnotetext{
Alamat korespondensi:

Karangmojo RT 05 RW 04, Teras, Boyolali

E-mail: lianurrahmawati467@gmail.com
}

ISSN 2252-6366 


\section{PENDAHULUAN}

Dalam rangka mencerdaskan kehidupan bangsa, dibutuhkan adanya pendidikan. Pendidikan sangat penting bagi semua orang. Namun tidak semua orang menyadari akan pentingnya pendidikan. Pendidikan merupakan proses yang saling berhubungan satu sama lain, antara faktor satu dan lainnya saling mempengaruhi. Pendidikan merupakan pondasi utama dalam mengembangkan potensi sumber daya manusia yang berkualitas. Pendidikan memiliki peranan penting dalam perkembangan seseorang. Pendidikan dapat membantu mengembangkan serta mengarahkan potensi seseorang dalam memenuhi tujuan hidupnya. Hal ini sesuai dengan Undang-Undang No 20 tahun 2003 tentang Sistem Pendidikan Nasional Bab II Pasal 3 bahwa pendidikan nasional berfungsi untuk mengembangkan kemampuan dan membentuk watak serta peradaban bangsa yang bermartabat dalam rangka mencerdaskan kehidupan bangsa yang bertujuan untuk mengembangkan potensi peserta didik agar menjadi manusia yang beriman dan bertaqwa kepada Tuhan Yang Maha Esa, berakhlak mulia, sehat, berilmu, cakap, mandiri, dan nantinya diharapkan menjadi warga negara yang demokratis serta bertanggung jawab.

Dalam pasal 1 ayat 1 UU RI No 20 tahun 2003 Tentang Sistem Pendidikan Nasional menyatakan bahwa pendidikan merupakan suatu usaha sadar dan terencana yang bertujuan untuk mewujudkan suasana belajar dan proses pembelajaran menjadi lebih aktif supaya peserta didik secara aktif dapat mengembangkan potensi dirinya untuk memiliki kekuatan spiritual keagamaan, pengendalian diri, kepribadian, kecerdasan, akhlak mulia, serta ketrampilan yang diperlukan dirinya, masyarakat, bangsa dan negara. Salah satu cara mengukur tingkat keberhasilan pembelajaran siswa adalah dengan pola asuh orang tua dan kemampuan berfikir kritis.

Dalam pasal 1 ayat 1 UU RI No 20 tahun 2003 Tentang Sistem Pendidikan Nasional menyatakan bahwa pendidikan merupakan suatu usaha sadar dan terencana yang bertujuan untuk mewujudkan suasana belajar dan proses pembelajaran menjadi lebih aktif supaya peserta didik secara aktif dapat mengembangkan potensi dirinya untuk memiliki kekuatan spiritual keagamaan, pengendalian diri, kepribadian, kecerdasan, akhlak mulia, serta ketrampilan yang diperlukan dirinya, masyarakat, bangsa dan Negara.
Salah satu cara mengukur tingkat keberhasilan pembelajaran siswa adalah dengan pola asuh orang tua dan kemampuan berfikir kritis. Dengan adanya bimbingan dan perhatian maka akan berpengaruh terhadap keberhasilan anaknya, dengan begitu anak menjadi semangat dalam belajar sehingga anak akan mampu berfikir secara kritis.

Menurut Olds and Feldman, 1998 dalam Helmawati (2016:138) bahwa pola asuh orang tua sangat berpengaruh terhadap kepribadian anaknya.

Menurut Syamaun (2014:18) pola asuh orang tua sangat berpengaruh besar dalam proses pembentukan dibanding pengaruh yang diberikan oleh komponen pendidikan lain. Orang tua harus memperhatikan perkembangan anaknya dengan mendidik, melatih serta mengawasi dalam proses belajar sehingga proses belajar anak anak baik.

Pola asuh orang tua sangat diperlukan untuk meningkatkan prestasi belajar siswa. Apabila orang tua mendidik dan memperhatikan anaknya dengan baik maka hasil belajar anakpun juga menjadi baik. Selain bimbingan dari guru, anak juga sangat membutuhkan bimbingan orang tua dalam belajar. Orang tua harus sepenuhnya memberikan dukungan serta bimbingan untuk anaknya sehingga anak akan menjadi lebih semangat dalam belajar.

Menurut Susanto (2013: 121), berpikir kritis adalah kegiatan melalui cara berpikir tentang ide atau gagasan yang berhubungan dengan konsep yang diberikan atau masalah yang dipaparkan.

Dalam proses belajar mengajar, kegiatan melalui cara berfikir yang berhubungan dengan materi pelajaran yang diberikan guru menjadi masalah yang sangat penting bagi siswa. Karena apabila siswa dapat berfikir secara baik maka akan berpengaruh terhadap hasil belajarnya.

Peneliti melakukan prapenelitian di SDN Kecamatan Teras Kabupaten Boyolali perhatian orang tua terhadap belajar anak masih kurang,terdapat siswa yang masih suka membolos, terdapat nilai yang masih dibawah $\mathrm{KKM}$, terdapat orang tua yang masih suka memarahi anaknya, orang tua membiarkan anaknya belajar sendiri, beberapa anak masih kesulitan dalam mengingat dan menjawab pertanyaan secara kritis.

Tujuan dari penelitian ini adalah untuk mengetahui hubungan yang positif dan signifikan antara pola asuh orang tua dan kemampuan berfikir kritis siswa.

Berdasarkan penelitian yang dilakukan oleh Deti Ahmatika (2018) hasil penelitian 
menunjukkan terdapat hubungan yang positif antara kemampuan berfikir kritis siswa dengan pendekatan inquiry/discovery.

Berdasarkan penelitian yang dilakukan oleh Mira Lestari (2019), hasil penelitian diperoleh sebanyak $34,9 \%$ anak memiliki tingkat kemandirian rendah dan $65,1 \%$ memiliki tingkat kemandirian tinggi. Sebanyak $15,1 \%$ orang tua menggunakan pola asuh autoritarian dan $84,9 \%$ menggunakan pola asuh autoritative. Pola asuh dengan kemandirian anak memiliki hubungan yang signifikan dengan nilai X2 sebesar 11,335. Pola asuh autoritaive memiliki kontribusi lebih dalam menumbuhkan kamendirian anak daripada pola asuh autoritarian.

Berdasarkan penelitian yang dilakukan oleh Amare Misganaw Mihret, galata sitota dilgasa, tsigereda hailu marno (2019) hasilnya yaitu apabila orang tua mengasuh secara negative maka akan memberikan efek pada motivasi akademik siswa.

Rumusan masalah penelitian ini yaitu adakah hubungan antara Pola Asuh Orang Tua Dengan Kemampuan Berfikir Kritis Siswa Kelas III SDN Kecamatan Teras Kabupaten Boyolali.

\section{METODE PENELITIAN}

Penelitian ini merupakan penelitian kuantitatif, dan termasuk jenis penelitian korelasi. Menurut Sugiyono (2016:14) metode kuantitatif merupakan metode yang digunakan untuk meneliti pada jumlah populasi dan sampel tertentu, teknik dalam pengambilan sampel umumnya random, pengumpulan data menggunakan instrumen, serta analisis data kuantitatif atau statistik yang berlandaskan pada filsafat positivisme untuk menguji hipotesis yang sudah ditentukan. Subjek dalam penelitian ini adalah siswa kelas III SDN Kecamatan Teras Kabupaten Boyolali. Penelitian ini dilaksanakan di SD Negeri 1 Gumukrejo, SD Negeri 2 Gumukrejo, SD Negeri 2 Tawangsari, SD Negeri 1 Krasak, SD Negeri 2 Teras, SD Negeri 3 Banjarsari, SD Negeri Barengan, SD Negeri 2 Salakan. Teknik pengambilan sampel pada penelitian ini menggunakan Purposive Sampling sebanyak 128 siswa. Variabel dalam penelitian ini terdiri atas satu variabel bebas dan satu variabel terikat. Variabel bebas yaitu pola asuh orang tua sedangkan variabel terikat yaitu kemampuan berkomunikasi siswa.

Desain penelitian korelasi dalam penelitian ini menurut Sugiyono (68: 2016) adalah sebagai berikut :

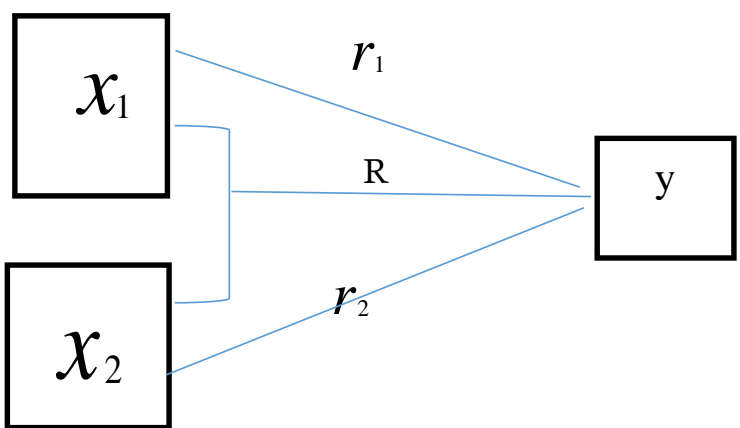

Gambar 1 Desain Penelitian Korelasi

$\mathrm{X}_{1} \quad=$ Pola asuh orang tua

$\mathrm{X}_{2} \quad=$ disiplin belajar

$\mathrm{Y} \quad=$ kemampuan berfikir kritis

$\mathrm{r}_{1} \quad=$ hubungan pola asuh orang tua dengan kemampuan berfikir kritis

$\mathrm{r}_{2}=$ hubungan disiplin belajar dengan kemampuan berfikir kritis

$\mathrm{R} \quad=$ hubungan antara pola asuh orang tua dan disiplin belajar secara bersama-sama dengan kemampuan berfikir kritis siswa.

Teknik pengumpulan data dengan wawancara, angket, tes, dan dokumentasi. Wawancara dilakukan dengan siswa kelas III. Angket digunakan dalam penelitian untuk mengumpulkan data variabel pola asuh orang tua. Tes digunakan untuk mengumpulkan data variabel kemampuan berfikir kritis siswa. Teknik analisis data yang digunakan pada penelitian ini adalah; (1) analisis uji prasyarat meliputi uji normalitas, dan uji linieritas, (2) analisis statistik deskriptif masing-masing variabel; dan (3) analisis data akhir untuk pengujian hipotesis menggunakan korelasi sederhana, analisis regresi sederhana, uji $\mathrm{F}$ (signifikan), dan koefisien determinasi.

\section{HASIL DAN PEMBAHASAN}

\section{Hasil Analisis Deskriptif}

Analisis deskriptif digunakan untuk mendeskripsikan data dari masing-masing variabel. Pada penelitian ini, deskripsi data yang dipaparkan meliputi deskripsi data variabel bebas yakni pola asuh orang tua serta deskripsi data variabel terikat yakni kemampuan berfikir kritis siswa Kelas SDN Kecamatan Teras Kabupaten Boyolali.

\section{Hasil Analisis Deskriptif Variabel Pola Asuh Orang Tua $\left(\mathbf{X}_{1}\right)$}

Data pola asuh orang tua diperoleh berdasarkan angket yang terdiri atas 36 item pernyataan. Hasil angket pola asuh orang tua yang terdapat di kelas III SDN Kecamatan 
Teras Kabupaten Boyolali dapat dilihat pada tabel berikut:

Tabel 1 Kategori Pola Asuh Orang Tua

\begin{tabular}{lllll}
\hline Interval & Kriteria & Frekuensi & Persentase & $\begin{array}{l}\text { Skor } \\
\text { rata- } \\
\text { rata }\end{array}$ \\
\hline $82-100$ & $\begin{array}{l}\text { Sangat } \\
\text { baik }\end{array}$ & 68 & $53 \%$ & 81 \\
& Baik & 57 & $45 \%$ & \\
$63-81$ & Cukup & 3 & $2 \%$ & \\
$44-62$ & Kurang & 0 & $0 \%$ & \\
Jumlah & & 128 & $100 \%$ & Baik \\
\hline
\end{tabular}

\section{Hasil Analisis Deskriptif Kemampuan Berfikir Kritis Siswa(Y)}

Data kemampuan berfikir kritis dalam penelitian ini diperoleh dari tes yang diberikan ke siswa kelas III SDN Kecamatan Teras Kabupaten Boyolali. Hasil tes kemampuan berfikir kritis yang terdapat di kelas III SDN Kecamatan Teras Kabupaten Boyolali dapat dilihat pada tabel berikut:

Tabel 2 Kategori Kemampuan Berfikir Kritis Siswa

\begin{tabular}{lllll}
\hline Interval & Kriteria & Frekuensi & Persentase & $\begin{array}{l}\text { Skor } \\
\text { rata- } \\
\text { rata }\end{array}$ \\
\hline $82-100$ & $\begin{array}{l}\text { Sangat } \\
\text { baik }\end{array}$ & 94 & $73 \%$ & \\
$63-81$ & Baik & 34 & $27 \%$ & 85 \\
$44-62$ & Cukup & 0 & $0 \%$ & \\
$25-43$ & Kurang & 0 & $0 \%$ & \\
Jumlah & & 128 & $100 \%$ & $\begin{array}{l}\text { Sangat } \\
\text { baik }\end{array}$ \\
\hline
\end{tabular}

Sebelum dilakukan analisis data akhir untuk mengujian hipotesis penelitian dilakukan uji prasyarat analisis data. Prasyarat analisis merupakan suatu syarat yang dikenakan pada kelompok data hasil penelitian untuk mengetahui layak atau tidak data tersebut dianalisis dengan menggunakan teknik statistik. Uji prasyarat analisis yang digunakan adalah uji normalitas untuk mengetahui data berdistribusi normal atau tidak. Statistik parametrik dapat digunakan jika data lolos uji normalitas. Selanjutnya, uji linearitas bertujuan untuk mengetahui dua variabel mempunyai hubungan linear atau tidak secara signifikan serta uji multikolinearitas yang berarti antara variabel bebas satu dengan variabel bebas lain tidak saling berkorelasi linear.

\section{Hasil Uji Prasyarat Uji Normalitas}

Uji normalitas dilakukan untuk mengetahui data pada setiap variabel yang dianalisis berdistribusi normal atau tidak.
Dalam penelitian ini, peneliti melakukan uji normalitas dengan bantuan SPSS versi 21. hasil perhitungan uji normalitas menunjukkan nilai sig. Kolmogorov Smirnov pada variabel pola asuh orang tua sebesar 0,103 dan variabel kemampuan berfikir kritis siswa sebesar 0,114. Hasil nilai signifikansi kedua variabel $>0,05$, maka dapat disimpulkan bahwa data variabel pola asuh orang tua dan variabel kemampuan berfikir kritis siswa berdistribusi normal.

\section{Uji Linieritas}

Uji linieritas digunakan untuk melihat garis regresi antara variabel X1 (pola asuh orang tua) dan Y (kemampuan berfikir kritis siswa), uji linieritas variabel pola asuh orang tua dan kemampuan berfikir kritis siswa menunjukkan nilai signifikansinya pada Deviation from Linierity sebesar 0,650. Karena nilai signifikansinya > 0,05 maka dapat disimpulkan bahwa antara variabel pola asuh orang tua dan kemampuan berfikir kritis siswa terdapat hubungan yang liniear.

\section{Uji Multikolinieritas}

Dari hasil uji multikolinieritas diketahui bahwa nilai Variance Inflation Factor (VIF) variabel bebas yaitu pola asuh orang tua sebesar 4,710 dan nilai tolerance sebesar 0,212 , karena nilai Tolerance $>0,10(0,212>0,10)$ dan nilai $\mathrm{VIF}<10,00(4,710<10,00)$ maka dapat disimpulkan bahwa tidak terjadi multikolinieritas terhadap data yang diuji.

\section{Analisis Hipotesis}

Analisis hipotesis dalam penelitian ini menggunakan analisis korelasi sederhana, uji signifikansi (uji F), dan uji koefisien determinasi.

\section{Hubungan Pola Asuh Orang Tua dengan Kemampuan Berfikir Kritis siswa}

Uji korelasi sederhana dalam penelitian ini menggunakan uji korelasi product moment dengan berbantuan program SPSS versi 21 .. Hasil perhitungan dapat dilihat pada tabel berikut:

Tabel 3 Hasil Uji Korelasi Pola Asuh Orang Tua terhadap Kemampuan Berfikir Kritis

\begin{tabular}{llll}
\hline $\mathbf{r}_{\text {hitung }}$ & $\begin{array}{l}\text { Taraf } \\
\text { Kesalahan }\end{array}$ & Sig. & $\begin{array}{l}\text { Uji } \\
\text { Determinasi }\end{array}$ \\
\hline 0,775 & 0,05 & 0,000 & $60 \%$ \\
\hline
\end{tabular}

Tabel tersebut menunjukkan bahwa uji korelasi pola asuh orang tua dengan kemampuan berfikir kritis diperoleh hasil

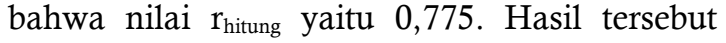


menunjukkan angka yang positif. Pada taraf signifikansi 0,05 diketahui nilai signifikansi dari tabel 4 yaitu $0,00(0,00 \leq 0,05)$, sehingga korelasi dikatakan signifikan. Hasil koefisien determinasi, diperoleh kontibusi pola asuh orang tua dengan kemampuan berfikir kritis siswa sebesar $60 \%$ sedangkan sisanya $40 \%$ dipengaruhi faktor lain.

Berdasarkan perhitungan tersebut dapat disimpulkan bahwa terdapat hubungan yang signifikan antara pola asuh orang tua dengan kemampuan berfikir kritis siswa kelas III SDN Kecamatan Teras Kabupaten Boyolali. Artinya, semakin tinggi tingkat pola asuh orang tua maka akan semakin baik pula kemampuan berfikir kritis yang diperoleh dan sebaliknya.

Hasil penelitian ini diperkuat dengan Penelitian oleh Hardiyanti pratiwi (2018), hasilnya bahwa paham radikal dapat dicegah dengan mengkondisikan anak untuk tumbuh dan berkembang dalam lingkup agama islam yang ramah dan penuh cinta. Anak yang mendapatkan pendidikan berlandaskan kasih saying dari orang tua akan tumbuh menjadi sosok yang mandiri, dewasa, mampu mengendalikan diri dan dapat menjalin hubungan social dengan baik.

Penelitian oleh Regina Sipayung (2018), hasil penelitian dan analisis tentang pola asuh orang tua dengan tingkat kedisiplinan siswa Siswa SD Kelas V di SD Negeri Muara Bolak 4 Kec. Sosorgadong diperoleh hasil thitung = 5,651 dan ttabel pada taraf signifikan 5\% sebesar 1,671 sedangkan ttabel pada taraf signifikan $1 \%$ sebesar 2,390. Hal ini berarti nilai thitung lebih besar dari nilai ttabel. Berarti dengan kata lain semakin baik pola asuh orang tua maka semakin tinggi tingkat kedisiplinan siswa.

Penelitian oleh Cindy Marisa, Evi Fitriyanti, Sri Utami (2018) hasilnya terdapat hubungan yang signifikan antara pola asuh orangtua dengan motivasi belajar remaja dengan kontribusi sebesar 18,8 \%, dimana sisanya peningkatan motivasi belajar dipengaruhi oleh faktor lain.

Penelitian yang dilakukan oleh Ni Luh Putu Diah Puspitasari, M.G.Rini Kristiantari, G.A.Agung Sri Asri (2018), berdasarkan uji hipotesis penelitian menunjukkan adanya korelasi yang positif antara pola asuh orang tua dengan disiplin siswa sebesar 0.987 serta dalam kualifikasi korelasi sangat tinggi. Hasil penelitian menunjukkan adanya hubungan dimana siswa yang nilai pola asuh orang tuanya rendah maka nilai disiplinnya juga rendah, atau sebaliknya siswa yang nilai pola asuh orang tua yang tinggi maka nilai disiplin belajar siswanya juga tinggi. Sehingga orang tua harus bisa meningkatkan kualitas pola asuh berupa penerapan pola asuh yang asertif demokratis.

Penelitian oleh Fatma Erdogan (2020) hasilnya yaitu ketrampilan berfikir kritis guru berbeda pada hal gender dan prestasi akademik tetapi ketrampilan berfikir reflektif guru sangat signifikan.

Penelitian yang dilakukan oleh Dasmo,dkk (2018), hasil penelitian menunjukkan 1) semakin baik pola asuh orang tua yang diterapkan terhadap anak maka akan semakin baik pula hasil belajarnya, 2) semakin baik kebiasaan belajar yang dilakukan siswa maka akan baik pula hasil belajarnya, 3) semakin baik pola asuh yang diterapkan dan semakin baik kebiasaan belajar yang dilakukan siswa secara bersama-sama akan semakin baik pula hasil IPA-nya.

Penelitian yang dilakukan Saira Yousaf (2015) hasil menunjukkan kecemasan sosila memiliki korelasi negative dengan harga diri tetapi tidak signifikan. Lalu hal itu menunjukkan harga diri yang akan menyebabkan kecemasan social berkorelasi negative dengan pola asuh permisif.

\section{SIMPULAN}

Sesuai hasil penelitian dan pembahasan, maka simpulan dari penelitian ini yaitu terdapat hubungan yang positif dan signifikan antara pola asuh orang tua dengan kemampuan berfikir kritis siswa SDN Kecamatan Teras Kabupaten Boyolali dengan nilai koefisien korelasi yaitu 0,775 dan nilai signifikansi 0,00 yang termasuk dalam kategori sangat kuat. Besarnya kontribusi variasi pola asuh orang tua terhadap kemampuan berfikir kritis siswa yaitu $60 \%$ sedangkan $40 \%$ dipengaruhi oleh faktor lain selain pola asuh orang tua.

\section{DAFTAR PUSTAKA}

Dasmo, Hikmah Binoardi, Zakiah Fithah A'ini. Peran Pola Asuh Orang Tua dan Kebiasaan Belajar Terhadap Hasil Belajar IPA. Jurnal Formatif ISSN: 2088351X, 27-38

Ahmatika, Deti. Peningkatan Kemampuan Berfikir Kritis Siswa dengan Pendekatan Inquiry/Discovery. Jurnal eucild vol 3 no 1 ISSN 2355-1712, 66-78.

Lestari, Mira. (2019). Hubungan Pola Asuh Orang Tua dengan Kemandirian Anak. Jurnal Pendidikan Anak ISSN 23026804,83-90. 
Marisa, Cindy, dkk (2018). Hubungan Pola Asuh Orang tua dengan Motivasi Belajar Remaja. Jurnal Konseling Dan Pendidikan ISSN 2337-6740, 45-55.

Mihret, Amare Misganaw dkk.2019.Parenting style as correlates of adolescents' academic achievement motivation of bate secondary school, haramaya, Ethiopia. Jurnal Pendidikan dan Literasi Siswa ISSN 2202-9478, 172-184.

Ni Luh Putu Diah Puspitasari, dkk. 2018. Korelasi Pola Asuh Orang Tua Dengan Disiplin Belajar Siswa Kelas VI SD Gugus VIII Sukawati Tahun Ajaran 2017/2018. Jurnal Fot Lesson And Learning. P-ISSN 2615 - 6148, e- ISSN 2615-7330, 96-108.

Pratiwi, Hardiyanti. (2018). Redefinisi Peran Orang Tua Dalam Pendidikan; Penanaman Sikap Anti Radikalisme Sejak Usia Dini. Jurnal Pendidikan dan Pembelajaran p ISSN 1979-5599. 108-122.

Regina Sipayung. 2018. Pengaruh Pola Asuh Orang Tua dan Disiplin Belajar Siswa SD Kelas V di SDN Muara Bolak 4 Kec. Sosorgadong. Jurnal Ilmiah Maksitek Universitas Katolik ST Thomas Medan ISSN: 2548-429X
Shochib, Moh. 2014. Pola Asuh Orang Tua Dalam Membantu Anak Mengembangkan Disiplin Diri. Jakarta: PT. Rineka Cipta.

Slameto. 2013. Belajar dan Faktor-Faktor yang Mempengaruhi. Jakarta: PT. Rineka Cipta.

Sugiyono. 2016. Cara Mudah Menyusun Skripsi, Tesis, dan Disertasi. Bandung: Alfabeta.

Sugiyono. 2015. Metode Penelitian Pendidikan Pendekatan Kuantitatif, Kualitatif, dan $R \& D$. Bandung: Alfabeta.

Sugiyono. 2016. Statistika Untuk Penelitian. Bandung: Alfabeta.

Syamaun, Nurmasyithah. 2014. Dampak Pola Asuh Orang Tua \& Guru Terhadap Kecenderungan Perilaku Agresif Siswa. Jogjakarta: Ar-Ruzz Media.

Yousaf, Saira. (2015). The Relation between Self-esteem, Parenting Style and social Anxiety in girls. Journal of Education and Practice ISSN 2222-1735, 139-150.

Erdogan, Fatma. (2020). The Relationship Between Prospective Middle School Mathematics Teachers' Critical Thinking Skills And Reflective Thinking Skills. Participatory Educational Research ISSN 2148-6123, 220-235. 